\title{
eLyra
}

REVISTA DA REDE INTERNACIONAL LYRACOMPOETICS

\section{A escrita em rede de Paula Glenadel}

\author{
Manuela Quadra de Medeiros \\ Universidade Federal de Santa Catarina - Capes
}

Resumo: Rede, da poeta, professora, ensaísta e tradutora Paula Glenadel, é o que podemos chamar de um livro sem gênero definido. Partindo dessa indefinição, o objetivo desse trabalho é pensar alguns caminhos para acessar essa linguagem que, de acordo com a própria autora, aproxima-se de um "pensamento-escrita". A publicação, que traz a palavra "Poesia" logo abaixo do título Rede em sua folha de rosto, joga a todo momento com as possibilidades que a escrita poética põe em cena, sendo escrita em forma de peça de teatro, com diálogos e personagens que brincam com o hibridismo da escrita contemporânea.

Palavras-chave: Paula Glenadel, rede, poesia, hibridismo

\begin{abstract}
Rede, by the poet, teacher, essayist and translator Paula Glenadel, is what we can call a book with no defined genre. Starting from this lack of definition, the purpose of this work is to think of some ways to access this language that, according to the author herself, approaches a "written-thought". The book, which contains the word "Poetry" just below the title Rede in its title page, plays all time with the possibilities that poetic writing puts on the scene. Written as a play, it has dialogues and characters that put the book in relation to the hybridity of contemporary writing.
\end{abstract}

Keywords: Paula Glenadel, network, poetry, hybridity 


\section{Rede}

Rede é o título do último livro de poesia de Paula Glenadel, publicado em 2014 pela editora do Rio de Janeiro Confraria do Vento, como parte da série "Os Contemporâneos". Mas, também, rede fala de uma espécie de cena ou de jogo ${ }^{1}$ de escrita que busco, aqui, seguir a partir da linguagem de Paula Glenadel - não só nesse livro, mas em seus diversos textos, sejam eles classificados em qualquer gênero literário ou acadêmico. Essa cena, então, é capaz de criar uma rede de discursos e de imagens, uma rede de pensamento da qual fazem parte diversas vozes, diversas máscaras, diversos personagens; em suma, uma rede que cria singularidades.

Em ensaio a respeito da obra da poeta contemporânea Nathalie Quintane - da qual Paula Glenadel também é tradutora do francês para o português -, a autora brasileira identifica um processo de "formagem":

A escritora francesa contemporânea Nathalie Quintane (nascida em 1964), em sua múltipla produção de textos que circulam entre poesia, prosa e teatro, vem apontando para uma dimensão da formagem - nem forma, nem formação, a formagem corresponderia a uma experimentação: a produção assistida de uma experiência através da escrita. [...] Em diferentes campos temático-discursivos, aparentemente externos ao que entendemos ainda por poético (o esporte, a infância, a linguística, a história e a fenomenologia do sapato, a Polônia, entre outros), trata-se, para essa autora, de realizar uma apropriação através da escrita de algo que não se tem, num processo sem fim. (Glenadel 2011: 273)

Esse processo sem fim, sem forma nem formação, de experimentação e de apropriação, que é denominado aqui de formagem por ser esse o título de livro de Quintane publicado em 2003, poderia também ser o nome do que estamos tratando aqui como rede. A possibilidade de mais de um nome já indica a sua característica heterogênea, de algo que não se pode nomear e que, por isso mesmo, pode ser nomeado sem cessar. Ao abrigar essa heterogeneidade, Glenadel diz que a noção de formagem "se converte em uma ferramenta teórica das melhores, ainda que ambivalente, ou justamente por isso [...] pode-se meditar sobre os processos de criação, sobre a citação, sobre a reciclagem de universos de linguagem" (idem: 276). Ou, como diz Walter Benjamin sobre seu trabalho das Passagens (1927-1940): "este trabalho deve desenvolver ao máximo a arte de citar sem usar aspas. Sua 
teoria está intimamente ligada à da montagem" (Benjamin 2009: 500). A arte de citar sem usar aspas, de fazer uso dos resíduos de teorias e de ideias, está presente tanto na dimensão da formagem de Nathalie Quintane (2003) quanto na dimensão da rede de Paula Glenadel (2014) e pode ser uma ferramenta para nos ajudar a pensar o uso que a autora brasileira faz da linguagem. Paula Glenadel é poeta, professora, ensaísta, crítica e tradutora, e toda essa pluralidade de "tarefas" parece fazer parte da sua linguagem em rede.

A formagem e a rede, portanto, são puro movimento, capaz de evocar multiplicidade e simultaneidade. Tanto na formagem como na rede, percebe-se a impossibilidade de fechamento do sentido, pois ele é sempre "ao mesmo tempo" e está sempre por vir. O pensamento em rede pode ser considerado o pensamento do disparate, um pensamento em espiral que vai até o limite do sentido e da linguagem, mas que não permite que a série se feche, pois há sempre desdobramentos que criam diferenças. No posfácio ao livro, Paula Glenadel fala da imagem da rede:

A imagem da rede, presente neste texto, que se inscreve na longa série de mutações da forma poesia, indica o tipo de trabalho que se desejou realizar aqui: um pensamento-escrita com a potência de tocar, ao mesmo tempo, na rede de discursos e imagens que norteiam a existência social humana e na rede de obras que constitui a tradição cultural e é matriz de qualquer novo trabalho artístico ou teórico. A rede é portadora de grande complexidade, sendo simultaneamente aprisionadora e liberadora, e merece, por isso, lugar de destaque no texto. (Glenadel 2014: 69)

Nesse livro de Paula Glenadel, penso que há três imagens mais evidentes da rede. Em primeiro lugar, há a imagem da capa, que nos mostra uma rede informe, sem começo nem fim, formada por traços, pontos e vazios. Trata-se da imagem de uma instalação artística de Chiharu Shiota, ${ }^{2}$ denominada Unconscious Anxiety. A instalação é composta por uma antiga mesa com máquina de costura (máquina de fiar) envolta por um emaranhado de fios-linhastraços pretos. A escolha da capa, assim como tudo na escrita de Glenadel, parece ter sido muito bem pensada. Vemos uma rede de complexidades tecida de trás para frente, de frente para trás, onde não há dentro nem fora, nem passado nem presente, nem um único começo, nem um único fim. 


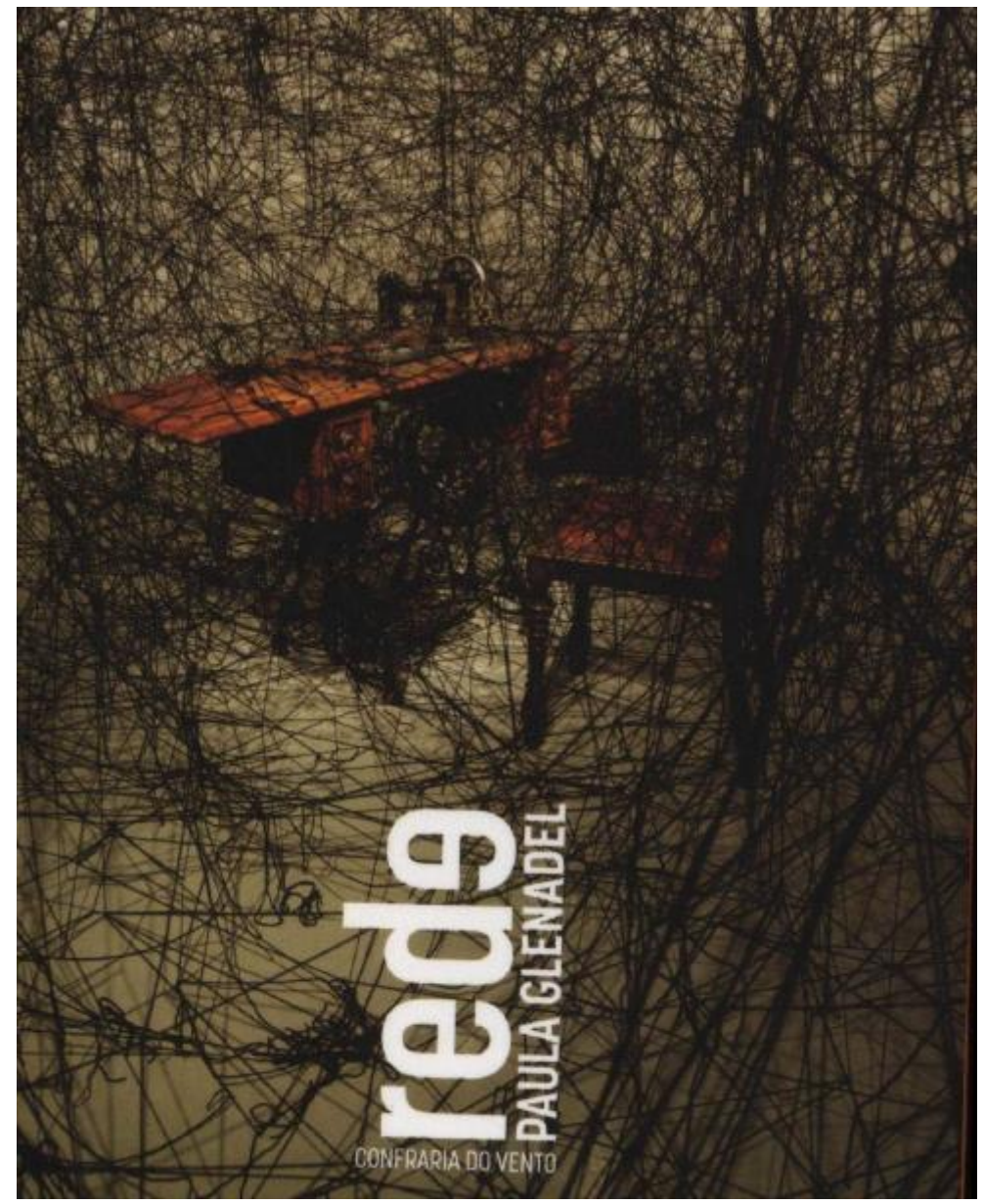

A segunda imagem seria a da rede como uma espécie de coletivo, quando algumas personagens falam da internet como uma rede de computadores, assim como falamos em rede elétrica e rede de esgoto, todas formando uma espécie de trama que interliga diversos pontos. A terceira seria a rede de descanso, que evoca desde o clássico Macunaíma (1928), de Mário de Andrade, deitado em sua rede, até Hélio Oiticica e sua instalação artística quasicinema, que convida os espectadores a assistirem, deitados nas redes penduradas, imagens em movimento projetadas na parede. Esta ideia de rede é a última que aparece no livro, quando o personagem Judas Nefasto faz uma performance que consiste no próprio artista dormindo em uma rede negra enquanto se ouve uma gravação.

Dessa forma, nessa proliferação de sentidos, Paula Glenadel potencializa a possibilidade de ambivalência e de simultaneidade da rede. Segundo o posfácio, a rede da autora busca tocar, aprisionar e libertar duas outras redes - que, por sua vez, têm a possibilidade de tocar inúmeras outras. Lembremos, pois, que esse não é um simples 
"tocar", mas, sim, algo que afeta o que foi tocado, que exerce certa força e certa influência sobre isso. Paula Glenadel fala, então, em "rede de discursos e imagens que norteiam a existência social humana" e em "rede de obras que constitui a tradição cultural" (ibidem). Ora, essa espécie de distinção entre duas "redes culturais" feita apenas no posfácio não é percebida no mundo dos personagens do livro, pois essa rede heterogênea possibilita justamente uma espécie de desierarquização entre discursos, imagens e obras, sem fronteiras entre o "alto" e o "baixo". Na Rede de Glenadel coexistem "Buda, um menino de cabeça raspada", os gêmeos "Maikon e Jakison, filhos da vizinha", "L’Amiral Larima", cujo nome é capaz de invocar o poema homônimo de Jacques Prévert em Paroles, de $1945,^{3}$ e muitos outros personagens que parecem estar sempre em relação a outro(s).

Assim, rede pode evocar, ao mesmo tempo, discursos e aporias, ruídos e silêncios, sendo, também ao mesmo tempo, "aprisionadora e liberadora". Um texto "que se inscreve na longa série de mutações da forma poesia" (ibidem) já expõe sua ambivalência e suas inúmeras possibilidades de leitura e de deslocamentos de sentido. Claro que, neste artigo, não temos a pretensão nem a ilusão de esgotar os sentidos possíveis da rede ou de trazer à baila tudo o que está nesse dentro-fora dela - até porque isso não seria possível. O que buscaremos é seguir alguns desses fios que formam a rede à medida que eles estão sendo fiados, a fim de abrir ainda mais caminhos, não importando a direção nem o destino, em uma espécie de percurso sem começo nem fim.

Em texto para a revista Remate de Males, Paula Glenadel fala sobre o seu movimento de escrita:

Em primeiro lugar, do ponto de vista dessa relação com uma origem (igualmente inventada, como todo o resto) da escrita, eu diria que escrever para trás é homenagear as leituras que fiz, toda a história da literatura, os livros que li e os que ainda vou ler, como fluxo, manancial, corrente subterrânea de escrita. Seria uma perspectiva meio barthesiana, segundo a qual a leitura desperta no leitor o desejo de se tornar autor, configurando o que ele chama de um erotismo da leitura. Neste patamar de reflexão, escrever para frente seria o jorro desse desejo tornando-se ele também escrita literária, indo encontrar o oceano de livros existentes para ali se perder. Nesse sentido, os escritores não deixariam de ser também, de certo modo, os trabalhadores do mar... (Glenadel 2010: 249) 
Ou seja, a rede de Paula Glenadel movimenta-se tanto em direção ao que foi quanto ao que virá, movimenta-se para frente e para trás, sem distinção. Trata-se de da escrita como um "jorro de desejo" impossível de ser contido, na qual é também impossível determinar um começo e um fim, já que eles parecem ser a mesma coisa: o oceano, ao mesmo tempo multidão e deserto. A escrita a partir da "corrente subterrânea" faz-se entre o fluxo do que contaminou o leitor e o jorro do desejo de se tornar autor. Portanto, a escritora Paula Glenadel está o tempo todo contaminada pela tradutora e leitora Paula Glenadel, sendo impossível dissociar as duas (ou três) tarefas. Assim, Paula Glenadel traz para suas próprias obras poéticas os dilemas suscitados pela leitura e pela tradução de textos de outros autores. Desse modo, a poeta cria um espaço nebuloso entre a tarefa do tradutor - para usar o termo de Walter Benjamin - e a tarefa do escritor. Para dar um exemplo desse movimento de escrita, penso na relação de Paula Glenadel com Nathalie Quintane. Vejamos o poema de Glenadel "A Voz (Poema Enfarinhado)" e o poema sem nome do livro Mortinsteinck (1999) de Nathalie Quintane:

\author{
Enquanto eu fazia um bolo \\ confusa entre verso e bolo \\ o verso solou \\ o bolo acabou \\ se outrora se fazia \\ verso com fermento \\ e em outro mais outrora \\ o verso tinha receita
}

agora o que seja verso

já nasce solado

a voz chega ázima

escarpada e carpina

mas olhando bem

agorinha mesmo

verso já nem nasce verso 
e agora, Maria? (Glenadel 2008: 70)

Pensa-se, teme-se, quando se prepara um boeuf bourguignon, não preparar verdadeiramente um boeuf bourguignon, quando se escreve poesia (verso, campos, blocos, ou linhas, ou frases, ou proposições) não estar escrevendo isso, quando se faz um filme, não estar suficientemente dentro do cinema - ou demais, o que dá no mesmo, porque a postura que consiste em querer a qualquer preço se situar na Nouvelle Cuisine, na Antipoesia, ou no Não Cinema, produz efeitos idênticos, já que ela apresenta a fixação a um lugar, e a consequente obrigação que teria o que se faz de entrar nele, ou de desejar apenas estar nele, como um imperativo. (Quintane apud Glenadel 2012: 57-58)

Walter Benjamin, no texto "A Tarefa do Tradutor", para além da Überleben, ou a sobrevida, joga com a palavra Fortleben, que seria continuar a viver, viver para além. Para traduzir este termo, Haroldo de Campos propôs o neologismo pervivência, aproveitando-se, acredito, de palavras em português que permitem essa construção, como "perdurar", por exemplo. Segundo Benjamin, "na sua pervivência (que não mereceria tal nome, se não fosse transformação e renovação de tudo aquilo que vive), o original se modifica" (Benjamin 2011: 107). Também no mesmo texto, Benjamin fala da tarefa do tradutor como sendo a de "liberar a língua do cativeiro da obra por meio da recriação (Umdichtung)" (idem: 117). Além de dar uma sobrevida ao poema de Nathalie Quintane ao traduzi-lo e fazê-lo circular entre os leitores de língua portuguesa, Paula Glenadel parece querer dar outra vida, parece querer fazer perviver a discussão sobre a própria poesia que aparece no poema de Quintane. E que, claro, vai aparecer também no poema de Glenadel. As duas parecem fazer a poesia ressoar no mundo ao trazer para o poema universos que seriam externos à questão da poesia, como o ambiente doméstico, a preparação de receitas, a cozinha e a comida. Esses outros universos, no entanto, são utilizados pelas poetas para problematizar a própria questão da poesia, de uma espécie de "crise do verso" para falar com Mallarmé (1863-1866). O que seria a verdadeira poesia? Para fazê-la, seria preciso de receita, como para fazer um bolo ou um bouef bourguignon? É preciso estar dentro do universo da poesia para escrever poesia? Como escrever versos, se o verso já nasce solado? Essas e outras perguntas emergem de ambos os textos, é essa a problematização que Paula Glenadel faz perviver em renovação, em transformação, em transplantação para além da obra original que ela traduz do francês. 


\section{Não}

Raul Antelo, no texto "A Aporia da Leitura", pergunta-se, em relação à poesia de Drummond, "como desatar o que o poema não desata mas justapõe problematicamente?" (Antelo 2002: s/p) - no caso de Glenadel, a própria questão da poesia, da linguagem, da tradução. Em seguida, Antelo elabora uma saída:

A resposta, a meu ver, encontra-se numa leitura que não veja o poema como uma forma mas como uma força. Uma força para-consistente. A força não é singular como a forma. Ela sempre se define em relação a outras forças, donde o conceito de força nos remete diretamente ao de pluralidade. [...] A força é o poder de um sujeito soberano, mas é também o objeto sobre o qual esse domínio é exercido. Portanto, uma força define-se como uma relação entre forças. Ela é uma pluralidade que sempre busca, passivamente, ser afetada por outras forças mas quer, simultaneamente, incidir ativamente sobre outras forças. Em suma, a força está sempre no meio do caminho, no entrelugar de determinação e desejo. (idem: 38)

É preciso, portanto, para poder acessar um caminho em direção à linguagem poética de Paula Glenadel, considerar o seu pensamento-escrita - como ela mesma o descreveu - como força e não como forma. Em outras palavras, é preciso ver a linguagem pensamento-escrita de Paula Glenadel como essa força para-consistente - lembrando que o prefixo "para" pode designar, ao mesmo tempo, a proximidade e a distância, a semelhança e a diferença, a interioridade e a exterioridade. ${ }^{4}$ A linguagem de Glenadel faz-se nessa rede capaz de tocar, ao mesmo tempo, duas fontes de palavras:

Quanto ao gênero, esta ficção crítica vem se situar na confluência de duas fontes de palavra. O seu jogo consistiria em in-separá-las. Se, a princípio, numa visão mais convencional do saber e da linguagem, pode-se relacionar o que à crítica (foco: ter, conhecer o objeto) e o quem à performance ou à ficção (foco: ser, erigir-se sujeito), em tempos de pós-crítica, de pós-poesia, de pós-dramático, e de biopolítica, porém, coisas e seres se confundem, de modo às vezes ameaçador, às vezes promissor. (Glenadel 2014: 69)

O que está posto em jogo, posto em cena, aqui, é justamente a questão da pluralidade, a não identificação do sujeito consigo mesmo, visto que ele é, ao mesmo tempo, sujeito e objeto. A rede que formaria a linguagem de Paula Glenadel está, assim, sempre em 
relação a outras redes de discurso, sejam elas relacionadas ao que da crítica e da filosofia, aos conceitos, seja aos personagens, ao quem da poesia e da ficção. É nesse meio do caminho, nesse entrelugar entre determinação e desejo, nessa zona de circulação de sentidos, que a escrita de Paula Glenadel se faz, ao mesmo tempo em que fazemos o nosso caminho em direção a ela.

No texto "Como se Fosse Possível, 'within such limits'...", Jacques Derrida, a partir da distinção entre o que e o quem que tenta justamente abalá-la, busca atingir um lugar anterior à distinção, um lugar a partir do qual a distinção aparece, "um lugar que de uma só vez prescreva a determinação, mas também torne possível a tradução terrivelmente reversível do 'quem' no 'quê'”' (Derrida 2004: 266). Essa tradução reversível do quem no que ou do que no quem mostra a impossibilidade dessa distinção. Chama atenção que Derrida nomeie isso de lugar, de local, de espaçamento e de intervalo, pois isso nos diz que o lugar deles e da própria distinção não é fixo, mas, sim, movente. É a partir dessa zona de circulação que Paula Glenadel pode criar o que ela chama de personagens conceituais, que relacionam-se, de modo indiscernível, tanto ao que quanto ao quem. Isso nos leva à questão, ainda, da recusa da figuração e do problema do nome e da nomeação, que veremos mais adiante.

\section{Quase}

No texto "Quase-Evento. Sobre a estoricidade da experiência literária", Alexandre Nodari discute dois termos que podem nos ajudar a trilhar esse caminho em direção à linguagem de Paula Glenadel: o quase-evento e a encenunciação, servindo este último à demanda de marcar a indiscernibilidade entre enunciação e encenação, uma vez que "texto e performance não se relacionam como potência e ato [...] fora e dentro da história, mas por meio de um fazer específico, uma experiência especial que dobra um sobre o outro, modificando a ambos e a seu estatuto" (Nodari 2017: 60). Correndo o risco de soar repetitiva, ressalto que a encenunciação também se faz em relação com a força paraconsistente e com o fazer da poesia: encenar e enunciar, indiscernidamente. Sobre a questão do quase, Nodari diz: 
Por isso, inspirando-nos em uma formulação de Eduardo Viveiros de Castro (2009), segundo a qual o "quase acontecer algo [... é] um modo de acontecer outra coisa que aquele algo", talvez possamos caracterizar a performance de uma enunciação literária como um quase-evento. "Quase" em dois sentidos, conexos entre si: 1) o primeiro, de uma proximidade ontológica que, porém, importa uma distância ainda que infinitesimal, pois nenhuma performance realiza plenamente e de uma vez por todas a enunciação fictícia, convertendo-a em um evento histórico determinado e definitivo, fazendo da estrutura um evento pleno: esta passagem, que se realiza a cada performance, é também, a cada vez e no mesmo gesto, adiada, como se a eventualização do texto poético fosse o limite (assintótico) ao qual tendesse, sem jamais alcançar, toda performance, toda leitura - não um limite externo e negativo, mas um limite interno, constitutivo, positivo; não um limite que não pode ser transgredido, mas um que, ao contrário, impele, é motor; 2) o segundo é a acepção etimológica de quase, como se (quasi é uma contração de quam si, e quam, por sua vez, o é de quo modo, como, ao modo de), que remete à encenação, a algo que está ao modo de outro, o que deve ser lido em seu sentido radical de sobreposição (dobradura) paradoxal do contraditório, pois toda encenação implica não só a dramatização de um outro, como também do próprio paradoxo de ser ao mesmo tempo a si mesmo e ao outro. (idem: 60-61)

É interessante pensar que esse "sentido radical de sobreposição paradoxal do contraditório" acontece também em relação à rede de escrita-pensamento-linguagem de Paula Glenadel. Na sua linguagem, as coisas parecem estar sempre ao modo de outro: poesia ao modo de teatro, crítica ao modo de poesia. No capítulo do livro Rede "As Férias do Saber", por exemplo, Maria Rima e Hipnos parecem discutir tanto o verso rimado como a verdade da poesia, colocando em cena a questão da poesia e de seus limites. Hipnos pergunta: "Você acha que a circunstância faz o poema?", e Maria Rima responde: "Me parece uma ideia razoável. Muito mais do que 'a ocasião faz o ladrão'. Só que não rima. Você sabia que aquilo que rima fica parecendo que é verdade? É o fundo dos provérbios" (Glenadel 2014: 26). De repente, o diálogo entre os dois é interrompido pelo Homem da Máscara de Cão. A figura do cão remete à discussão proposta pelo poeta francês Jean-Marie Gleize, que distingue, na poesia de Baudelaire, a tensão entre uma "poesia-gato", relacionada a uma espécie de alta poesia, que seria lírica, e uma prosa-cão, errática e sem qualquer pretensão de elevação. No ensaio “Figuras de Prosa. A Ideia da 'prosa' como questão de poesia", Marcos Siscar resume bem a discussão da aproximação entre a prosa e a poesia: 
Não por acaso, a aproximação coincide com as ambivalências (ou "contradições") da assim chamada "modernidade" e tem um ponto de referência fundamental em Baudelaire, autor de Spleen de Paris (ou Pequenos Poemas em Prosa), livro que vem ganhando prestígio na fortuna crítica recente do autor. É em Spleen de Paris que Gleize, por exemplo, encontrará as evidências de algo como um ideal baixo da literatura, por oposição ao ideal alto de As Flores do Mal, opondo ao mistério sublime dos gatos (fechados nas quatro paredes dos poemas em verso) a figura mais prosaica do cachorro (que passa sem destino pelas ruas dos poemas em prosa). (Siscar 2015: 32)

No livro de Paula Glenadel, a questão fica ainda mais interessante por não se tratar exatamente de um cão, mas sim de um homem com uma máscara do animal, um homem como que metamorfoseado em cão. ${ }^{5}$ Ou seja, poderíamos pensar em uma poesia travestida de prosa, ou mesmo uma prosa travestida de poesia: uma poesia que se faz ao modo de outro.

Por isso podemos dizer que a escrita de Paula Glenadel faz-se nesse interregno do quase, e assim podemos falar em quase um teatro e em encenunciação, uma vez que essa escrita toca e faz-se nesse limite interno constitutivo. Ou, ainda, dizer que a linguagem pensamento-escrita de Glenadel faz-se nessa radicalidade da sobreposição paradoxal do contraditório, da ausência e da presença, do eu e do outro, do possível e do impossível. Paula Glenadel fala, no ensaio "Mais Um no Oceano", a partir do lance de dados de Mallarmé (1914), que esse tudo ou nada só poderia acabar de modo razoável no quase. 0 jogo teatral da linguagem de Paula Glenadel, nesse espaço heterogêneo, parece se fazer sempre entre: um entre entendido como um lugar de borda, mas também de contato, uma espécie de fronteira. ${ }^{6}$ Como diz a personagem Premiê Onira, "um limbo, entre a manchete e a nota de rodapé" (Glenadel 2014: 60). Ou na ambivalência do cogumelo, que, segundo a autora, vive "na fronteira entre vegetal e animal" (ibidem). A tensão do entre - entre ninguém e alguém, entre ausência e presença, entre o sonho e a vigília - faz-se presente em todo o livro Rede. Uma enigmática carta, encontrada dentro de um bolso de casaco comprado em brechó, e que parece movimentar as cenas do livro, diz:

Gosto de olhar essas coisas porque elas estão ali - para ninguém. E elas me dão uma inexistência rara. Sendo para ninguém, elas me tornam ninguém. Ninguém, porém, as olhou como eu. Isso faz de mim um ninguém especial, quase um alguém. (idem: 20-21) 


\section{Teatro}

Ao final do posfácio ao livro Rede, Paula Glenadel afirma que "A vantagem, deste teatro mental, é a leveza resultante do incógnito da maioria das obras e propostas evocadas, a maior liberdade de criar personagens conceituais e, principalmente, a alegria da inconclusão" (idem: 70). O que Paula Glenadel chama de "teatro mental" no posfácio pode ser entendido, nas palavras da própria autora, quando ela refere-se à poeta francesa Nathalie Quintane, como um "ato performativo que resulta numa exploração da complexa relação humana com a linguagem" (Glenadel 2012: 17); o "teatro mental" como uma experiência de leitura que seja também uma experiência de vida ao abrir para o leitor a possibilidade de ordená-lo, de interpretá-lo, de fazê-lo (re)significar, indo além da mera representação naquilo que Glenadel chama, em tom bem humorado, de "comédia da interpretação". O "teatro mental", de Valéry, ou ainda a mise en scène spirituelle, de Mallarmé, poderia ser essa ficção crítica carregada de subjetividade que Paula Glenadel pratica e que, segundo ela, garante maior liberdade, uma vez que, assim como o teatro proposto por Antonin Artaud, essa encenunciação se apresenta enquanto linguagem à medida que vai se constituindo diante do leitor-espectador. A questão da "leveza resultante do incógnito" também é interessante para pensar aquilo que é não conhecido, podendo ser colocado na esteira de uma espécie de não saber. Paula Glenadel diz

assim se mostra a poesia para mim: uma ginástica interior visando a uma liberdade maior, a uma espécie de alforria, um modo de naufragar bem, quer dizer, de naufragar bastante e alegremente, de entrar no não saber da coisa toda, de sustentar o vício da dúvida entre perceber e conhecer, tudo isso na certeza visceral de que pensar pesa. $^{7}$

É preciso demorar-se um pouco nessa pequena citação, uma vez que ela nos lança para inúmeras outras redes de forças que são forças em rede. Em primeiro lugar, é interessante pensar na questão da "ginástica interior" e do "não saber" com Georges Bataille e sua noção de experiência interior. Afirmar a alegria da inconclusão e visar a uma alforria, um modo de naufragar bem, é reconhecer a precariedade do discurso, reconhecer que a linguagem não é capaz de traduzir a complexidade da experiência e do pensamento; por isso 
é preciso, justamente, mergulhar na precariedade a fim de encará-la, a fim de fazer um uso da linguagem cada vez mais distante da representação. Diz Bataille que

a experiência interior responde à necessidade em que estou [...] de pôr tudo em causa (em questão) sem repouso admissível. [...] As pressuposições dogmáticas deram limites indevidos à experiência: aquele que já sabe não pode ir além de um horizonte conhecido. (Bataille 2016: 33)

É por isso que, para Glenadel, é tão importante "sustentar o vício da dúvida" e abraçar a "leveza resultante do incógnito". A "linguagem do projeto" de que fala Bataille em A Experiência Interior também é interessante para pensarmos a linguagem de Paula Glenadel. Bataille escreve que

no entanto, a experiência interior é projeto, queiramos ou não. Ela o é já que o homem também o é inteiramente através da linguagem, que, por essência, exceção feita à sua perversão poética, é projeto. Mas o projeto deixa de ser neste caso aquele, positivo, da salvação e torna-se aquele, negativo, de abolir o poder das palavras, logo, do projeto. (idem: 55)

A "perversão poética" da linguagem, portanto, seria a única capaz de abolir o poder das palavras e do projeto, de modo que a linguagem da poesia sacrifica a utilidade da língua. O personagem João Silêncio, no livro Rede, ao sentir-se seduzido por traduzir um poema em prosa de Max Jacob, e abandonar por hora a retradução do livro dos sonhos, diz:

eu estava traduzindo uma passagem específica do livro, com forte presença de expressões servis (não esqueça que ele foi escrito na época da terceira guerra servil), e o lacaio de Jacob me fez ver com outros olhos a condição servil. Eu a vi, por causa do poema, com os olhos do lacaio ou do cão, e não do Conde Spagati. (Glenadel 2014: 39)

João Silêncio parece buscar destruir a finalidade de "servir para" da língua, ou seja, seu caráter utilitário, por meio da tradução e da poesia, que, segundo Bataille, seria o sacrifício no qual as palavras são as vítimas. Ainda sobre o personagem João Silêncio, que é escritor e tradutor, outro personagem, Judas Nefasto, diz "Tomemos o exemplo de João Silêncio. Tudo o que ele faz parece predestinado a se corromper de dentro. O projeto é ridiculamente abolido por sua própria execução" (idem: 67). Ou seja, ao tentar salvar o livro 
dos sonhos de uma tradução ruim, João Silêncio tenta retraduzi-lo, em um projeto que não pode ter outro destino que não o fracasso do projeto. Ou, ainda, sendo silêncio, um silêncio que só aparece como a palavra que é "a abolição do barulho que a palavra é; entre todas as palavras, é a mais perversa, ou a mais poética: ela própria é a garantia de sua morte" (Bataille 2016: 48).

Em segundo lugar, a certeza da autora de que "pensar pesa" nos leva a Jacques Derrida e sua ideia de plus d'une langue, que está intimimamente ligada com a desconstrução. Em Carneiros, Derrida, a partir de um poema de Paul Celan, diz que "Pensar é também, em latim tal como em francês, pesar, compensar, contrabalançar, comparar, examinar. Mas para isso, para pensar e pesar, é então preciso portar, portar em si e portar em cima de si" (Derrida 2003: 17). Além disso, diante do idioma alemão da escrita de Celan, Derrida faz ainda uma aproximação entre pensamento e reconhecimento, agradecimento denk e dank:

\footnotetext{
Mas se nós não temos a sorte desta colisão ou deste jogo entre pensamento e gratidão, e se o comércio do agradecimento se arrisca sempre a permanecer uma compensação, temos, nós, nas nossas línguas latinas, esta amizade entre pensar e pesar (pensare), entre o pensamento e a gravidade. Entre o pensamento e o porte, ou a carga. Donde o exame. O peso de um pensamento chama e chama-se sempre o exame, e sabeis que exame é, em latim, a agulha de uma balança a que se confia a justeza, e talvez a justiça, de um juízo sobre o que se lhe dá a portar ou a carregar [porter]. (ibidem)
}

A relação entre pesar, pensar e agradecer pode ser entrevista no endereçamento que Paula Glenadel faz do seu livro Rede, quando ela o envia "ao mundo, seja lá o que isso for, com meus agradecimentos" (Glenadel 2014: p.). Ao mundo, a esse não saber que é o mundo e que o constitui, Paula Glenadel endereça seu livro com seu agradecimento, seu reconhecimento, seu pensamento e seu pesar. Ou, ainda, seus pêsames, visto que a personagem Psiquê declara "O mundo já acabou, você não sabia? Desde o tempo da vanguarda. Tem pelo menos um século. Mas estamos aqui assim mesmo. Ainda estamos aqui" (Glenadel 2014: 27).

Há, pelo menos, duas visões de mundo muito interessantes que perpassam o trabalho poético de Paula Glenadel. Seriam, a meu ver, o mundo-esponja, do poema 
"Verões": "Rio, fevereiro: a umidade /e a chuva fundem / gente, água, terra, ar, / numa coisa só - / tudo, um mundo-esponja. // Entro (em mim): / sou de madeira inchada / estalo e empeno // e haverá outros verões" (Glenadel 1999: 32) Ou seja, um mundo que parece inchar, de tanto absorver tudo, como uma esponja. E, também, o mundo-brechó que entrevejo no livro Rede, a partir de alguns atos que se passam em um brechó, onde é encontrada a enigmática carta que movimenta alguns personagens do livro. Em entrevista a Sérgio Medeiros para a revista Qorpus, Paula Glenadel fala sobre a imagem do brechó:

O brechó, na verdade, é um lugar muito interessante, onde todo tipo de coisas parecem ganhar vida, onde elas nos interpelam - sobre o humano, como não poderia deixar de ser. Os surrealistas, de certo modo, inventam essa alegoria, ao elegerem como extremamente interessantes os precoces dejetos da sociedade industrial, pela vertiginosa poesia do envelhecimento desses objetos que surgem como promessas de uma novidade estonteante, mas já contêm na origem a sua ruína. O interesse deles pelos "mercados das pulgas" é bem revelador. Por isso, coloquei uns quadros surrealistas no porão. 0 brechó também é um lugar de desierarquização cultural, de hospitalidade, onde o cacareco mais reles convive com o objeto de luxo abandonado, passado adiante. ${ }^{8}$

Ou seja, o presente, para Paula Glenadel, pode ser percebido como esse corredor estreito de um brechó amontoado. O brechó é o lugar da descontinuidade da história. Ambos os tempos estão prontos para serem ressignificados. O passado e o presente como tempos de mundo(s) de desierarquização cultural, onde tudo pode ganhar vida, onde as coisas nos interpelam, onde o "alto" convive com o "baixo", onde as coisas são como que profanadas, tendo seus usos restituídos de outras formas, onde há espaço para os dejetos, onde até a novidade mais estonteante contém em si a sua ruína. Ou seja, é diante desse mundo-brechó, anacrônico, que também contém em si a sua ruína, ou melhor, que é um amontoado de ruínas, é diante desse mundo, virando as costas para o futuro, "abrigo inóspito", que Paula Glenadel parece escrever sua linguagem-pensamento em rede, sempre inacabada e sempre ainda em devir.

\section{Mais de um}

O personagem João Silêncio também coloca em cena a questão do peso do pensamento, e, mais ainda, a questão do peso do nome, quando diz, logo no primeiro 
capítulo do livro, que seu nome está lhe pesando. “Oi, Maria Rima. Meu nome está me pesando, sabia? Preciso encontrar um pseudônimo para assinar o livro que estou terminando. Pensei em Ferdinand de Personne... O 'de' é fundamental... O que é que vocês acham?" (Glenadel 2014: 15). O silêncio do nome que lhe pesa é o silêncio de uma aporia que o faz pensar, peso e pensamento que o colocam em movimento. Pesa o silêncio de um lugar privilegiado ao pensamento. Ao escolher outro nome, ao se doar um nome para, digamos, poder assinar seu livro, João Silêncio coloca-se no lugar performativo por excelência: performa a figura do autor. Ele pensa, então, em um nome francês que remete ao poeta português Fernando Pessoa. Mas "personne", em francês, é ambivalente e pode significar tanto ninguém como alguém. Não esquecendo que o "de" seria fundamental: Fernando de Alguém; Fernando de Ninguém. O "de" é como que um pertencimento, uma filiação. O que também nos faz pensar, misturando as possibilidades, no nome "João Ninguém", que designa alguém absolutamente anônimo. Assim, entre o nome mais comum, "João", e o nome da pura heterogênese, "Fernando Pessoa", Paula Glenadel, com esse personagem, coloca em cena e joga com as questões do nome comum, do nome próprio e da sua intraduzibilidade, as quais foram caras para o pensamento de Derrida.

A questão do nome dos personagens (são, mais ou menos, 20 personagens) nesse livro é muito interessante, e nele, inclusive, dedica-se uma cena somente para a chamada de nomes em uma aula de história da arte, da qual participam a professora Maria Rima e alunos como $A(m)$ nésia, com " $m$ " mudo; Armando César; Constância Bárbara; Cristina Dolores; Glauber e Ítala Helena, para citar alguns. Há, também, no livro, personagens com nomes "em alemão" como Gottwald e "em francês" como L'Amiral Larima e Nasser Ville. Coloco "em alemão" e "em francês" entre aspas pois acredito que os nomes fazem-se também nessa relação entre as línguas, nessa pluralidade de linguagem. Ao usar nomes em outros idiomas, Paula Glenadel como que esvazia o sentido desses nomes, abrindo diversas possibilidades de preencher o vazio da linguagem - ou de simplesmente deixar o nome rodar nesse vazio. No texto "Vórtices", Giorgio Agamben diz que

os nomes - e cada nome é um nome próprio ou um nome divino - são vórtices no devir histórico das línguas, remoinhos nos quais a tensão semântica e comunicativa da linguagem se bloqueia a si mesma 
até se tornar igual a zero. No nome, já não dizemos - ou não dizemos ainda - nada, chamamos somente. (Agamben 2014: 61)

\section{E conclui:}

o nome é, na verdade, um vórtice que fura e interrompe o fluxo semântico da linguagem, mas não simplesmente para aboli-lo. No vórtice da nomeação, o signo linguístico, girando e afundando-se em si mesmo, intensifica-se e exacerba-se ao extremo, para depois se deixar sugar no ponto de pressão infinita em que desaparece como signo, para reaparecer noutro lado como puro nome. E o poeta é aquele que mergulha neste vórtice, em que tudo volta a ser para ele nome. Ele deve retomar uma a uma as palavras significantes do fluxo do discurso e lançá-las no turbilhão, para reencontrá-las no vulgar ilustre do poema enquanto nomes. Estes são algo que alcançamos - se é que os alcançamos somente no final da descida no vórtice da linguagem. (ibidem)

Ao interromper o fluxo semântico da linguagem de seu livro com um capítulo em que apenas nomes são chamados, Paula Glenadel parece levar ao limite essa tensão comunicativa da linguagem, chamando a atenção, cada vez mais, para a palavra e não para o sentido. É mais ou menos o que acontece quando o personagem João Silêncio diz que a palavra "angústia" Ihe dá calafrios e que, por isso, ele prefere "angoisse, acho mais elegante, meio irritado, meio enfadado, assim como se a pessoa não quisesse se entregar ao abismo acentuado da angústia" (Glenadel 2014: 19). A diferença, então, entre angústia e angoisse não está no sentido, mas, sim, na palavra, na sua grafia, na sua sonoridade, na sua pronúncia, na sua enunciação - ou melhor, na sua encenunciação.

A questão do nome aparece também no trabalho, digamos, ensaístico de Paula Glenadel. No ensaio "Mais Um no Oceano", ela responde à já clássica pergunta feita a escritores - "Por que escreve?". A resposta de Paula Glenadel, como não poderia deixar de ser, parte para uma espécie de problematização do "eu":

A pergunta, sabiamente, engole o pronome, o você, e se coloca na terceira pessoa. Isso colabora com a resposta, pois eu vou transitar entre o "por que você escreve" e o "por que escreve". Entre o pessoal e o impessoal. Entre eu (meu sobrenome é maior) e a ficção que inventei, um autor de literatura, de poesia, uma poeta, a Paula Glenadel. Também me faço esta pergunta, periodicamente, e Ihe acrescento outras. Por que escrevo? Por que a Paula Glenadel escreve? Por que eu tenho que explicar o que ela faz? [...] E o fato de eu (que sou a inventora da poeta) estar respondendo (por ela) à 
pergunta Por que escreve? mostra isso [o encontro da poesia e do teatro] muito bem. No teatro, pelo menos tal como ele está sendo pensado aqui em direção ao poema, nesse mínimo teatro que eu imagino (uma mise en scène spirituelle, diria ainda o santo Mallarmé), a autonomia das vozes é um espetáculo do qual inclusive o tenebroso "eu lírico" pode desfrutar. Então, eu posso me imaginar pedindo a um dos personagens para responder a essa pergunta e me divertindo com a sua resposta. (Glenadel 2010: 247)

Paula Glenadel, autora de literatura e de poesia, faz-se também em um espaço de ficção; a máscara da escritora faz-se como uma personagem-conceito, assim como os que ela cria para o quase-teatro livro Rede. Retornando um pouco ao posfácio do livro Rede, já citado aqui, percebemos, em uma leitura atenta, que nele não há uma implicação do "eu". A autora escreve sobre o "tipo de trabalho que se desejou realizar", usando, no lugar do sujeito, o chamado índice de indeterminação do sujeito. O esvaziamento da persona, sua indeterminação, portanto, faz-se também no posfácio, e intensifica o jogo entre presença e ausência quando encontramos, ao final, a assinatura "Paula Glenadel". O "tenebroso eulírico" também pode desfrutar desse espetáculo que é a autonomia das vozes, mas no livro Rede ele participa somente enquanto ausência, parecendo querer desestabilizar e tensionar ainda mais esse espaço de encontro.

A escrita do ensaio de Paula Glenadel deixa ver uma linguagem bem-humorada, que faz usos dos recursos da linguagem para mantê-la sempre em movimento, metamorfoseando-se em metáfora, em caricatura, em ironia, paródia e no que mais a autora quiser, mantendo a sua linguagem-pensamento-escrita heterogênea. Giorgio Agamben estabelece relações entre a paródia e a ficção, em ensaio do livro Profanações:

\footnotetext{
Mas, realmente, a paródia não só não coincide com a ficção como constitui o seu oposto simétrico. De fato, a paródia não põe em dúvida, como faz a ficção, a realidade do seu objeto - este, aliás, é tão insuportavelmente real que se trata, precisamente, de mantê-lo à distância. Ao "como se" da ficção, a paródia contrapõe seu drástico "assim é demais" (ou "como se não"). Por isso, se a ficção define a essência da literatura, a paródia se põe, por assim dizer, no limiar dela, obstinadamente estendida entre realidade e ficção, entre a palavra e a coisa. (Agamben 2007: 46)
}

Na poética de Paula Glenadel, cabem tanto o "como se" quanto o "como se não", ou melhor, o "assim é demais", visto que a ambivalência da paródia deve ser entendida como 
algo que excede deste gesto paródico, algo que resta, que deixa vestígios. A rede de sentidos de Glenadel é justamente o que permite essa heterogeneidade discursiva, que quebra a linguagem bem-comportada, a linguagem fenomenológica, permitindo, por meio dessa ambivalência, o disfarce, a simulação, o travestimento e, claro, o movimento da linguagem. O teatro de Paula, portanto, é visto não como uma imitação, mas como esse discurso de travestimento, em que há translações de sentidos, que são capazes de criar imagens a partir da simulação, da montagem. Nesse caso, portanto, é preciso sempre ler a frase, seu duplo e sua negação ao mesmo tempo, visto que há sempre mais de um nome, mais de um sentido, mais de uma direção, mais de uma língua em cena, encenando e enunciando a própria linguagem e seus limites.

\section{A voz}

Neste breve e último passo de um caminho que tentamos percorrer no dentro-fora dessa rede de discursos e pensamentos, tento elaborar uma conclusão a partir das cenas finais do livro Rede. No penúltimo capítulo, intitulado "O Sono", o antes pintor e agora performer Judas Nefasto inaugura sua performance. Pensando, primeiro, na nomeação do personagem, temos o nome de Judas, o traidor da Bíblia, e o adjetivo nefasto, que vem do latim nefastus ou nefaris, palavras relacionadas àquilo de que não se deve falar. $\mathrm{Na}$ descrição da cena, lemos:

Na galeria, Judas Nefasto dorme um sono profundo, induzido por narcóticos. Os convidados chegam para o vernissage e o encontram deitado numa rede negra, rendada como uma teia de aranha. Ouve-se uma gravação com a voz dele. (Glenadel 2014: 63)

A voz gravada de Judas Nefasto nos diz: "Repito. Repito. Repito. A obra. A desobra. Dá no mesmo... Repito. Repito. Repito. A obra. A desobra. Dá no mesmo... Repito. Repito. Repito. A obra. A desobra. Dá no mesmo "(ibidem). Alguns personagens, diante do ato, tentam interpretar a performance. Hipnos acha tudo um tédio, e lamenta pelo artista ter sido um pintor tão bom e agora querer fazer performance. Maria Rima tenta defender o artista, dizendo que todos fazemos performance o tempo todo por aí. Hipnos retruca dizendo que isso já foi feito antes. Ao que Psiquê explica: “Por isso ele diz 'repito'. Não é só 
porque ele repete a mesma frase na gravação. O diferencial está na rede. É uma performance antropofágica, você não percebe? Os índios é que dormem em redes" (idem: 65). Tia Angústia pergunta-se o que será que o artista quis dizer quando diz que "dá no mesmo", "o que é que dá no mesmo?" L’Amiral Larima responde: “Ora Angústia, essa é fácil: o que dá no mesmo é o outro. Como dizia meu velho companheiro Jacques Prévert, de duas coisas, uma, a outra é a segunda. Entretanto, essa minha tradução é bastante livre, devo observar" (ibidem). Antes de irem embora, Maria Rima diz que vai ler um texto que fez recentemente pensando na obra de Nefasto. Esse texto é o único que aparece em versos no livro Rede:

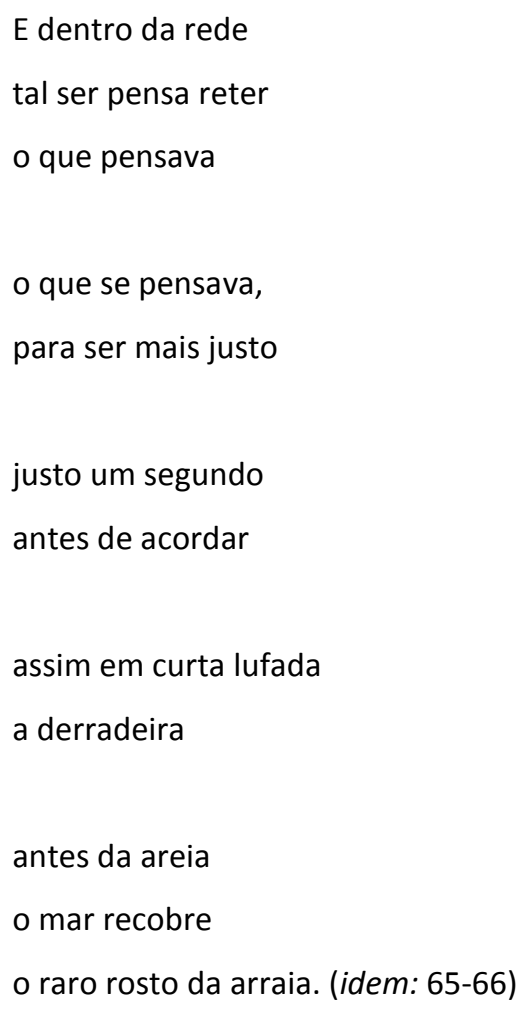

Tentando reter o que pensava, ou o que se pensava, o que ele pensava ou pelo que ele era pensado, Judas Nefasto, dentro dessa rede, coloca-se como sujeito e objeto da arte ao mesmo tempo. Diz Bataille em A Experiência Interior:

não há mais sujeito = objeto, mas "brecha escancarada" entre um e outro, e, na brecha, o sujeito, o objeto, se dissolvem, há passagem, comunicação, mas não de um ao outro: o um e o outro perderam a existência distinta. As perguntas do sujeito, sua vontade de saber são suprimidas: o sujeito não está 
mais ali, sua interrogação não tem mais sentido nem princípio que a introduza. Da mesma forma, nenhuma resposta permanece possível. A resposta deveria ser "tal é o objeto", quando não há mais objeto distinto. (Bataille 2016: 94)

Entre um e outro, entre eu e outro, entre outro e o mesmo, entre sujeito e objeto não há mais identificação nem distinção. "Dá no mesmo", como diz o personagem. Após todos deixarem a galeria onde acontecia a performance, exceto Judas, que permanece dormindo, passamos ao último capítulo-cena do livro, intitulado "O Rolo". A descrição da cena nos mostra "Judas, sozinho na galeria, desperta. Tem um papel enrolado dentro da boca. Cospe-o. Lê:

Um segundo antes de acordar para uma encenação, para uma encarnação, um texto sonha. No seu sonho, ele age. $O$ texto trabalha dormindo. Ele é puro futuro sonâmbulo. Que ele cumpra, enfim, se for capaz, o seu destino. Que, enquanto peça, não seja mais do que pedaço, recorte, retalho, fragmento: quase. Os seus personagens estão, como não podia deixar de ser, meio perdidos, no meio do caminho. Tomemos o exemplo de Cristina Dolores, por assim dizer, crucificada entre dois mundos incompatíveis. Tomemos o exemplo de João Silêncio. Tudo o que ele faz parece predestinado a se corromper de dentro. $\mathrm{O}$ projeto é ridiculamente abolido por sua própria execução. Talvez o personagem mais importante seja aquele que aparece menos, que fala menos. Quem sabe? A ação ramifica. Muitas linhas se entrelaçam e o traçado pode ser seguido de muitas maneiras. Muitos mundos são convocados, ainda que compareçam apenas pelos seus embriagantes estereótipos. 0 modo de ser da rede, sendo armadilha, é sedução. A paixão que alguns personagens têm pelos discursos, alguns francamente detestáveis, tem um quê de trágico. Afinal, como se diz, o peixe morre pela boca. Mas deixemos os estereótipos de lado, eles são crescidos o bastante para sobreviverem sem nós. Nós estamos tentando crescer o bastante para vivermos sem eles. E em nosso percurso, ficamos mais fortes, aprendemos a gostar de tudo. Dá no mesmo. Essa lição de Judas Nefasto parece ainda guardar algum frescor. É preciso meditá-la sempre, ruminá-la até que ela se abra como um fruto em nossa boca. (Glenadel 2014: 67-68)

Ainda que seja um pouco longa, vale a pena trazer na íntegra essa citação que parece ser como uma espécie de epílogo, quase um posfácio, mas lida - e não dita - por um personagem do livro que é performer. Nessa cena, Judas Nefasto não faz mais que performar a linguagem. Ele não fala, ele lê o que sai da boca dele já escrito. Sua fala não é como a linguagem que vai-se fazendo enquanto é proferida. Talvez por isso seja tão difícil 
pensar a experiência da linguagem, pois no momento mesmo de registro ela já é outra coisa. O texto coloca em cena também a questão da autoria, já que ele fala do próprio Judas Nefasto não como um "eu", mas como um "outro". A lição que ele busca nos ensinar é que "dá no mesmo". É interessante lembrar que Judas Nefasto fala para uma sala vazia, ou seja, fala para ninguém. É como diz o texto da carta encontrada no brechó, que os personagens tentam decifrar e que fora escrita, depois eles viriam a saber, pelo próprio Judas Nefasto, enquanto ainda era pintor: "Sendo para ninguém, elas [as coisas] me tornam ninguém. Ninguém, porém, as olhou como eu. Isso faz de mim um ninguém especial, quase um alguém" (idem: 20-21). Falando para ninguém, Judas Nefasto, de quem não se deve falar, também torna-se ninguém - sempre nesse jogo de não distinção entre um e outro, entre alguém e ninguém: quase um alguém. Um performer cuja performance consiste em dormir. Um texto que trabalha dormindo e que só age no sonho. Um texto que não pode ser nada além de fragmento. A paixão pelo discurso como algo trágico. Tentar sobreviver sem estereótipos. Crescer a ponto de gostar de tudo. Uma ficção sem autor. A passagem da obra à desobra: dá no mesmo. Tudo isso demonstra certa inoperância diante do sistema convencional, daquilo que já está dado, de qualquer pressuposto, de qualquer a priori. Uma espécie de recusa da obra, uma renúncia a fazer obra, "indicando somente o espaço onde ressoa, para todos e para cada um, e portanto para ninguém, a fala sempre por vir do désœuvrement" (Blanchot 1983: 77). A fala sempre por vir da desobra e da inoperância, a vontade de vontade. Dá no mesmo. É preciso engolir e regurgitar a lição de Judas Nefasto até que ela se abra como um fruto em nossa boca. É preciso, por fim, ver o pensamentoescrita de Paula Glenadel, nessa linguagem em rede, como uma experiência que está sempre se fazendo, ou melhor, se refazendo, no fazer (e fazer de novo) que é próprio da poiesis, um modo de encenunciar a experiência da linguagem, de modo a senti-la em nossa boca e em nosso corpo. O sentido vai se fazendo e sendo tecido. 


\section{NOTAS}

1 Uso, nesse trabalho, cena e jogo quase como sinônimos, aproveitando a ambivalência do verbo jouer, em francês, spielen, em alemão, e to play, em inglês, que serve tanto para jogar como para encenar e até mesmo para tocar um instrumento, por exemplo.

${ }^{2}$ A respeito da artista, o Sesc-SP diz que: “em experiências mundo afora, ao suspender em cordões, organizar ou empilhar objetos usados, como cartas, chaves, camas, malas e sapatos, a artista se afeiçoou a construir verdadeiras teias sustentadas pelo passado e pelo presente, que evocam as camadas da memória e amadurecem um estilo em que a carga narrativa está contida na conjugação de experiências íntimas com o público". Disponível em <https://www.sescsp.org.br/online/artigo/compartilhar/9421_CHIHARU+SHIOTA + CONHECA+A+ARTISTA>.

3 “L'amiral Larima / Larima quoi / la rime à rien / l'amiral Larima / l'amiral Rien”.

4 uma coisa que se situa ao mesmo tempo aquém e além de uma fronteira, de um limiar ou de uma margem, de estatuto igual e, no entanto, secundário, subsidiário, subordinado, como um convidado para seu anfitrião, um escravo para seu senhor. Uma coisa em para não está somente e ao mesmo tempo dos dois lados da fronteira que separa o interior do exterior: ela é também a própria fronteira, a tela que se torna membrana permeável entre o dentro e o fora. Ela opera sua confusão, deixando entrar o exterior e sair o interior, ela os divide e une. (Hillis-Miller apud Genette 2009: 9)

Sobre o para, ver, também, a discussão de Derrida, a partir de Kant, do ergon e do parergon no livro La Vérité en Peinture, de 1978.

${ }^{5} \mathrm{O}$ antropólogo Eduardo Viveiros de Castro explica que a ideia de "roupa-máscara", para os ameríndios, seria uma das expressões privilegiadas da metamorfose:

A noção de metamorfose está diretamente ligada à doutrina das 'roupas' animais [...] Aqui me parece haver um equívoco importante, que é o de tomar a 'aparência' corporal como inerte e falsa, a 'essência' espiritual como ativa e verdadeira [...]. Nada mais distante, penso, do que os índios têm em mente ao falarem dos corpos como 'roupas'. Trata-se menos de o corpo ser uma roupa que de uma roupa ser um corpo. Estamos diante de sociedades que inscrevem na pele significados eficazes, e que utilizam máscaras animais (ou pelo menos conhecem seu princípio) dotadas do poder de transformar metafisicamente a identidade de seus portadores, quando usadas no contexto ritual apropriado. Vestir uma roupa-máscara é menos ocultar uma essência humana sob uma aparência animal que ativar os poderes de um corpo outro. (Viveiros de Castro 1996: s. p.)

${ }^{6}$ Ao analisar a poesia de Nathalie Quintane, Paula Glenadel escreve que a obra da poeta francesa dirige-se às fronteiras poéticas contemporâneas, que são, além de outras coisas, fronteiras "entre obra escrita e performance oral ou leitura pública de sua produção" (Glenadel 2012: 14).

${ }^{7}$ Site da autora, sem data.

8 Disponível em <http://qorpus.paginas.ufsc.br/\%e2\%80\%9c-a-procura-de-autor\%e2\%80\%9d/edicao-n017/entrevista-com-paula-glenadel-sergio-medeiros/>. 


\section{Bibliografia}

Agamben, Giorgio (2014), "Vortici", in Il Fuoco e il Racconto, trad. André Dias (com consulta de excertos traduzidos por Davi Pessoa), Roma, Nottetempo, 61-66.

-- (2007), Profanações, trad. Selvino José Assmann, São Paulo, Boitempo.

Antelo, Raul (2002), "A Aporia da Leitura", Ipotesis. Revista de estudos literários, v. 7, n 1, 31-45.

Artaud, Antonin (2006), O Teatro e seu Duplo, trad. Teixeira Coelho, São Paulo, Martins Fontes.

Bataille, Georges (2016), A Experiência Interior - Seguida de Método de Meditação e Postscriptum 1953: Suma ateológica, vol. I, trad. Fernando Scheibe, Belo Horizonte, Autêntica Editora.

Benjamin, Walter (2011), "A Tarefa do Tradutor", in Escritos sobre Mito e Linguagem (19151921), trad. Susana Kampff Lages e Ernani Chaves, São Paulo, Editora 34, Duas Cidades.

-- (2009), Passagens, trad. alemão Irene Aron, trad. francês Cleonice Paes Barreto Mourão, Belo Horizonte, Editora UFMG, São Paulo, Imprensa Oficial do Estado de São Paulo.

-- (1987), Obras Escolhidas, vol. 1, trad. Sérgio Paulo Rouanet, São Paulo, Editora Brasiliense. Blanchot, Maurice (1983), La Communauté Inavouable, Paris, Minuit.

Derrida, Jacques (2004), Papel-Máquina, trad. Evando Nascimento, São Paulo, Estação Liberdade.

-- (2003), Carneiros. O Diálogo Ininterrupto. Entre dois infinitos, o poema, trad. Fernanda Bernardo Coimbra, Palimage.

-- (1978), La Vérité en Peinture, Paris, Flammarion.

Genette, Gérard (2009), Paratextos Editoriais, trad. Álvaro Faleiros, São Paulo, Ateliê Editorial. 
Glenadel, Paula (2014), Rede, Rio de Janeiro, Confraria do vento.

-- (2012), Nathalie Quintane, Ciranda da Poesia, Rio de Janeiro, EDUERJ.

-- (2011), "Nathalie Quintane. Formagens", Alea, vol. 13, $\mathrm{n}^{\circ}$ 2, s.p., <http://www.scielo.br/scielo.php?script=sci_arttext\&pid=S1517-106X2011000200006> (último acesso em 30/03/2019).

-- (2010), “Mais Um no Oceano", Remate de Males, vol. 30, № 2, 247-251.

-- (2008), A Fábrica do Feminino, Rio de Janeiro, 7Letras.

-- (2005), Quase uma Arte, Rio de Janeiro, Cosac Naify / 7Letras.

-- (1999), A Vida Espiralada, Rio de Janeiro, Editora Caetés.

Medeiros, Sérgio (2015), "Entrevista com Paula Glenadel”, Qorpus, vol. 17, s.p., $<$ http://qorpus.paginas.ufsc.br/\%e2\%80\%9c-a-procura-de-autor\%e2\%80\%9d/edicao-n017/entrevista-com-paula-glenadel-sergio-medeiros/> (último acesso em 30/03/2019).

Nodari, Alexandre (2017), "Quase-evento. Sobre a estoricidade da experiência literária", Elyra, no 10, 55-77, <http://www.elyra.org/index.php/elyra/article/view/204> (último acesso em 30/03/2019).

Siscar, Marcos (2015), "Figuras de Prosa. A Ideia da 'prosa' como questão de poesia", in $O$ Duplo Estado da Poesia. Modernidade e contemporaneidade, São Paulo, Iluminuras, 29-40.

-- (2005), "O Animal que se Desconhece", in Glenadel, Paula, Quase uma Arte, Rio de Janeiro, Cosac Naify / 7Letras, pp. 7-10.

Viveiros de Castro, Eduardo (1996), “Os Pronomes Cosmológicos e o Perspectivismo Ameríndio", Mana, vol. 2, $\mathrm{n}^{\circ} \quad$ 2, s.p., <http://www.scielo.br/scielo.php?script =sci_arttext\&pid=S0104-93131996000200005\&lng=pt\&nrm=iso\&tlng=pt $>$ (último acesso em 30/03/2019). 
Manuela Quadra de Medeiros possui bacharelado e licenciatura em Letras Português e Literaturas de Língua Portuguesa pela Universidade Federal de Santa Catarina, Universidade pela qual também é mestre em Literatura - tendo defendido o trabalho de mestrado intitulado "Labirintos Autobiográficos: Lygia Clark e Hélio Oiticica" em 2015. Atualmente, cursa o terceiro ano de doutorado na mesma instituição, com auxílio da CAPES, dedicandose ao estudo da escrita poética da escritora contemporânea Paula Glenadel e suas relações com a poesia contemporânea. Seus principais focos de pesquisa são: poesia contemporânea, teatralidade da linguagem, história da poesia, história da arte e relações entre texto e imagem. 